\title{
Transmission of the Citrus Variegated Chlorosis Bacterium Xylella fastidiosa with the Sharpshooter Oncometopia nigricans
}

\author{
R. H. Brlansky, Professor, University of Florida, Citrus Research and Education Center, Lake Alfred 33850; V. D. \\ Damsteegt, Research Plant Pathologist, United States Department of Agriculture-Agricultural Research Service \\ (USDA-ARS), Foreign Disease-Weed Science Research Unit, Frederick, MD 21702; and J. S. Hartung, Research \\ Plant Pathologist, USDA-ARS, Fruit Lab, Beltsville, MD 20705
}

\begin{abstract}
Brlansky, R. H., Damsteegt, V. D., and Hartung, J. S. 2002. Transmission of the citrus variegated chlorosis bacterium Xylella fastidiosa with the sharpshooter Oncometopia nigricans. Plant Dis. 86:1237-1239.

Citrus variegated chlorosis (CVC) is an economically important, destructive disease in Brazil and is caused by the bacterium Xylella fastidiosa Wells. The bacterium has been found to be transmitted in Brazil by sharpshooter leafhoppers (Cicadellidae). Sharpshooters are present in most citrus growing areas of the United States. The sharpshooter leafhopper, Oncometopia nigricans Walker, frequently is found feeding on citrus in Florida. This sharpshooter transmits the $X$. fastidiosa strains that cause Pierce's disease of grape and ragweed stunt. Research was initiated to determine if $O$. nigricans was capable of vectoring the $X$. fastidiosa that causes CVC. In 59 different transmission tests, using 1 to 57 insects per test, transmission of the bacterium was observed 12 times $(20.3 \%)$. Symptom development in the greenhouse was not a reliable indicator of transmission. Transmission was verified by specific polymerase chain reaction-based assays. Individual insects were able to transmit the bacterium. This information on sharpshooter transmission of CVC is needed to assess the threat posed by the CVC disease to the citrus industries in the United States.
\end{abstract}

Additional keywords: leafhoppers, plant-pathogenic bacteria

Citrus variegated chlorosis (CVC) was described as a new disease of citrus in 1987 in Brazil (27) and later was found to be caused by the xylem-inhabiting bacterium Xylella fastidiosa Wells (8-10). The disease also has been reported from Argentina (6). Various strains or types of X. fastidiosa exist $(17,23)$ and cause many different diseases of commercial crops (24), one of which, Pierce's disease of grapevines, is well known in California $(13,14)$ and has long been a limiting factor for grape production in Florida (28). Pierce's disease of grapevines presently is causing increasing losses in California since the introduction of the glassy-winged sharpshooter, Homalodisca coagulata Say (21). CVC causes considerable economic losses in Brazil. In 2000, it was estimated that in the state of Sao Paulo, Brazil, 34\% of the 200 million trees have symptoms of the disease and, in 2001, the number of symptomatic trees increased to $36 \%$, with

Corresponding author: R. H. Brlansky

E-mail: rhby@lal.ufl.edu

Florida Agricultural Experiment Station Journal Series No. R-08505.

Accepted for publication 18 June 2002.

Publication no. D-2002-0820-02R

(c) 2002 The American Phytopathological Society
$24 \%$ having severe symptoms of leaf chlorosis and small fruit (2). Precise economic figures are not available; however, yields are definitely reduced and the small fruit are usually unmarketable (A. J. Ayres, Fundecitrus, Brazil, personal communication). The bacterium is transmitted by xylem-feeding sharpshooter leafhoppers (Homoptera: Cicadellidae, Cicadellinae; 11,12). Of 16 sharpshooter species tested in Brazil, 12 have been identified as vectors of CVC $(16,25)$. Sharpshooters are present in Florida and feed on citrus $(3,4)$; therefore, we initiated studies on the ability of a sharpshooter from Florida, Oncometopia nigricans Walker, to transmit the CVC bacterium. The methods developed in this study are now being applied to the glassy-winged sharpshooter $H$. coagulata, another sharpshooter species native to Florida. This information is needed to assess the threat posed by CVC disease to the citrus industries in the United States. Portions of this work have been presented as abstracts previously (5).

\section{MATERIALS AND METHODS}

$O$. nigricans sharpshooters were collected from a Lantana sp. (Lantana camara (L.) Moldenke) in central Florida. The Lantana sp. was planted as a trap crop in field plots between an area of native vegetation where sharpshooters were commonly found and an experimental citrus planting. During the months of August to October, adult sharpshooters were captured from the Lantana plants and put into screened cages which contained L. camera, 'Madame Vinous' sweet orange (Citrus sinensis L.), grape (Vinis vinifera L. 'Mission'), and periwinkle (Cathranthus roseus L. (G. Don)). The sharpshooters were allowed to feed on this mixture of plants for a period of 5 days, after which they were put into small plastic cages with cuttings of healthy periwinkle for overnight shipment to the United States Department of Agriculture-Agricultural Research Service, Foreign Disease-Weed Science Research Unit, Fort Detrick, MD. The original plants that the sharpshooters were caged on were observed for any symptoms of Pierce's disease and were tested for the presence of $X$. fastidiosa using membrane entrapment immunofluorescence (MEIF) (7) after 6 months.

After arrival at the Fort Detrick lab, the sharpshooters were placed on healthy sweet orange plants for $24 \mathrm{~h}$ of acclimation, then transferred onto CVC-infected sweet orange (Citrus sinensis L. 'Madame Vinous'). Symptomatic source plants had been previously inoculated by grafting buds from CVC-infected sweet orange samples received from Brazil. Source plants were confirmed positive for $X$. fas tidiosa by polymerase chain reaction (PCR)-based assays (18) prior to being used in these experiments. After an acquisition access period (AAP) of 24 to $48 \mathrm{~h}$, surviving sharpshooters were transferred to healthy 'Madame Vinous' sweet orange plants for a 48- to 72-h inoculation access period (IAP). Initial experiments were conducted with groups of $29,47,48$, $50,51,54$, and 57 sharpshooters that survived and fed on CVC-infected plants and then were transferred to single sweet orange plants. In secondary experiments, groups of $1,3,5,10$, and 20 sharpshooters were fed on CVC-infected plants for 24 to $72 \mathrm{~h}$ and then were placed on healthy sweet orange plants. The minimum IAP used was $12 \mathrm{~h}$ but, in some experiments, sharpshooters survived for up to 7 days.

The sweet orange plants were maintained in the greenhouse and allowed to grow. Assays were performed using PCR with specific primers designed for the CVC strain of $X$. fastidiosa (18). PCRbased assays were performed on the plants 
3 months later and at various time periods afterward. In the initial experiments, leaf petioles were assayed by immunocapture of the target bacteria followed by nestedPCR, as described by Pooler et al. (19). In subsequent experiments, petioles were assayed without immunocapture by stan- dard PCR using primer pair 272-1-int and 272-2-int (18). In these latter experiments, petioles were sliced and then extracted using the FastPrep system (Qbiogene, Carlsbad, CA). Leaf petioles also were assayed using MEIF designed for detection of the citrus canker bacterium Xanthomo-

Table 1. Transmission of citrus variegated chlorosis to 'Madame Vinous' sweet orange by the sharpshooter leafhopper, Oncometopia nigricans

\begin{tabular}{lccc}
\hline No. of sharpshooters per receptor plant & No. of tests & $\begin{array}{c}\text { Positive } \\
\text { transmissions }\end{array}$ & $\begin{array}{c}\text { Transmission } \\
(\%)\end{array}$ \\
\hline $47-57$ & 6 & 3 & 50 \\
$20-29$ & 4 & 0 & 0 \\
10 & 7 & 2 & 28 \\
5 & 11 & 1 & 9 \\
3 & 7 & 1 & 14 \\
1 & 24 & 5 & 20 \\
Totals & 59 & 12 & 20.3 \\
\hline
\end{tabular}

a Positive by nested polymerase chain reaction (PCR)-based assay (20) or by standard PCR using primer pair 272-1-int and 272-2-int (19).

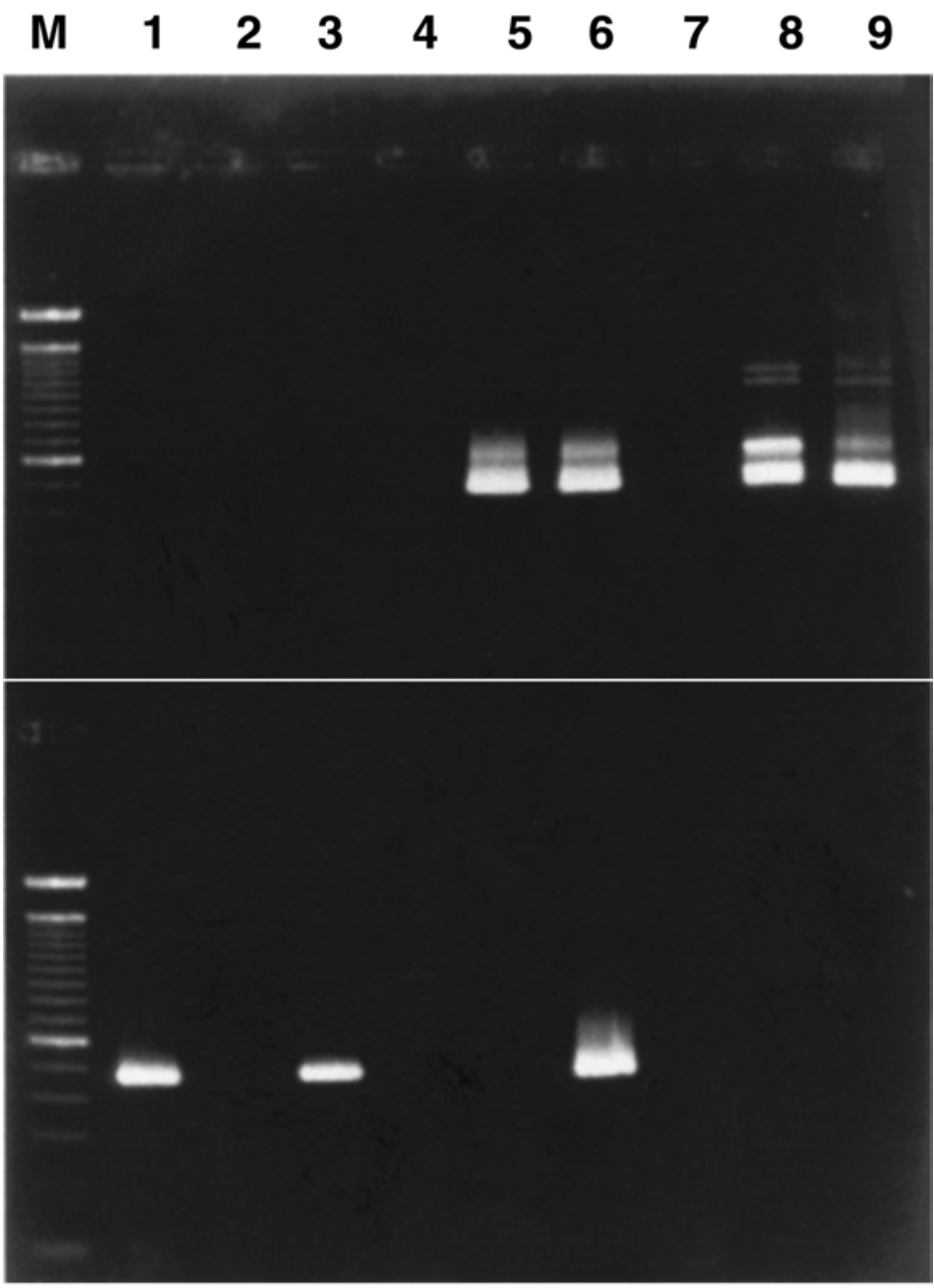

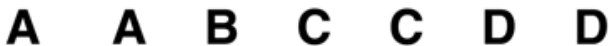

Fig. 1. Transmission of Xylella fastidiosa to sweet orange 'Madame Vinous' by the leafhopper Oncometopia nigricans. Detection of the specific polymerase chain reaction (PCR) amplification product after immunocapture and nested PCR amplification (20). Upper half gel: Lanes 1-4, healthy plant controls; lanes 5-6, infected source plants; lane 7, negative control; lanes 8-9, bacterial culture positive controls. Lower half gel: Seven test plants representing four separate experiments denoted A, B, C, and D. Lane M is a 100-bp DNA ladder (Life Technologies, Rockville, MD).

nas axonopodis pv. citri and the citrus bacterial spot bacterium $X$. axonopodis pv. aurantifolia (7).

\section{RESULTS AND DISCUSSION}

Plant assays. No symptoms indicative of Xylella fastidiosa caused diseases such as Pierce's disease of grape, periwinkle wilt, or CVC were found on any of the plant materials that the field-collected sharpshooters fed on prior to transmission experiments. MEIF assays of these materials were negative. Controls using the CVC-inoculated and symptomatic sweet oranges that were previously PCR positive also were positive in MEIF tests. These plants were used as CVC source plants for sharpshooter acquisition.

Transmission results. Fifty-nine sweet orange plants were infested with 1 to $57 O$. nigricans for a minimum of $24 \mathrm{~h}$ of IAP and presumed to be inoculated. However the overall transmission rates were $20.3 \%$ ( 12 of 59 plants were positive by PCR) and were scattered among insects sets (Table 1). The number of insects did not affect the rate of transmission as much as the length of active feeding. Single insects were good vectors if they were actively feeding during the acquisition and inoculation periods. Initially, transmissions were obtained with high numbers of sharpshooters (47 to 57) These results were obtained even though a limited number of tests were done (Fig. 1) using relatively large plants in three-gallon pots. Successful transmissions also were obtained with $10,5,3$, and 1 sharpshooters. Of the plants used for single sharpshooter transmissions, 20\% tested positive. More transmission tests were conducted using single sharpshooters because small plants could accommodate from 1 to 5 sharpshooters, whereas larger plants had to be used when 10 or more sharpshooters were used. When using high numbers of sharpshooters, from 47 to 57 , the bacterium was transmitted to $50 \%$ of the test plants. We found that small plants that are actively growing are more susceptible to infection by $X$. fastidiosa than are larger plants, and the bacterium is more easily detected in such plants. This could contribute to the relatively high transmission rates observed in the single insect experiments.

Sharpshooters may acquire and transmit the bacterium without a latent period or without the bacteria colonizing the precibarium or cibarium of the insect. Sharpshooters lose the ability to transmit colonized bacteria after molting (20).

Symptom expression of CVC in greenhouse-grown citrus plants is not easily obtained (10). Even with graft-inoculated or culture-inoculated plants, the expression of the typical chlorotic leaf spots and the variegated chlorosis symptoms seen in field plants often are missing. We have seen typical symptoms vanish in subsequent plant growth flushes. Many of the plants used in sharpshooter transmission 
work showed good symptoms which often disappeared in the subsequent months. Other plants showed a mild chlorosis that was unlike the symptoms described for CVC. The reason for this is unknown, but it may be that full symptom expression requires nutrient or water stress, which were not present during the course of the experiments reported herein. Symptom expression was inconsistent; therefore, PCR assays specific for the CVC bacterium were a better indication of infection.

In Brazil, 12 of the 16 species of sharpshooters tested have been shown to transmit the CVC Xylella sp. to citrus (15). Most species transmitted at an efficiency rate of lower than 5\%; however, two species, Macugonalia leucomelas and a Bucephalogonia sp., transmitted at rates of 11 and $17 \%$, respectively. These transmission rates are similar to our results with $O$. nigricans (Table 1).

The glassy-winged sharpshooter, $\mathrm{H}$. coagulata, was introduced into California around 1990 and was identified in 1994 (1). This sharpshooter has continued to expand its numbers and range in California $(16,21)$. It now is found in most of Southern California and has been found south of Bakersfield and in Sacramento. It was found to transmit the $X$. fastidiosa strain that causes oleander leaf scorch disease (22) and, since then, has been found to transmit the $X$. fastidiosa strain that causes Pierce's disease of grape (21). Large populations of this sharpshooter are found in many parts of California, feeding and laying eggs on various types of citrus (lemon and orange) and other host plants (macadamia, apricot, oak, and others). The ability or efficiency of this sharpshooter to transmit the bacterium that causes CVC is unknown. Experimental work is currently underway to determine this. Given the high populations of this insect in California citrus, if the glassy-winged sharpshooter is shown to transmit the CVC strain of $X$. fastidiosa, the threat of establishment of the CVC strain should be considered serious. Coffee leaf scorch disease recently has been reported in Costa Rica (26). This may mean that CVC also is present because there is a close relationship between CVC and coffee leaf scorch diseases and their causal bacteria.
The ability of the $O$. nigricans sharpshooter to vector the CVC strain of $X$. fastidiosa is important to Florida citrus. Should the causal agent of CVC be introduced into Florida, a vector is already present that will spread this important bacterial pathogen.

\section{LITERATURE CITED}

1. Anonymous. 1994. Calif. Plant Pest Dis. Rep. 13:(Numbers 1-2): 8-10.

2. Anonymous. 2002. CVC challenges Fundecitrus. Pages 16-19 In: Fundecitrus: Relatorio de Gestao 1995-2002.

3. Adlerz, W. C. 1980. Ecological observations on two leafhoppers that transmit the Pierce's disease bacterium. Proc. Fla. State Hortic. Soc. 93:115-120.

4. Adlerz, W. C., and Hopkins, D. L. 1979. Natural infectivity of two sharpshooter vectors of Pierce's disease of grape in Florida. J. Econ. Entomol. 72:916-919.

5. Brlansky, R. H., Damsteegt, V. D., Howd, D. S., and Hartung, J. S. 1996. Transmission of the causal agent of citrus variegated chlorosis, Xylella fastidiosa, with a sharpshooter leafhopper vector from Florida. (Abstr.) Phytopathology 86:S74.

6. Brlansky, R. H., Davis, C. L., Timmer, L. W., Howd, D. S., and Contreras, J. 1991. Хylem-limited bacteria in citrus from Argentina with symptoms of citrus variegated chlorosis. (Abstr.) Phytopathology 81:1210.

7. Brlansky, R. H., Lee, R. F., and Civerolo, E. L. 1990. Detection of Xanthomonas campestris and $X$. citri from citrus using membrane entrapment immunofluorescence. Plant Dis. 74:863-868

8. Chagas, C. M., Rossetti, V., and Beretta, M. J. G. 1992. Electron microscopy studies of a xylem-limited bacteria in sweet orange affected with citrus variegated chlorosis disease in Brazil. J. Phytopathol. 134:306-312.

9. Chang, C. J., Garnier, M., Zreik, L., Rossetti, V., and Bove, J. M. 1993. Culture and serological detection of the xylem-limited bacterium causing citrus variegated chlorosis and its identification as a strain of Xylella fastidiosa. Curr. Microbiol. 27:137-142.

10. Hartung, J. S., Beretta, M. J. G., Brlansky, R. H., Spisso, J., and Lee, R. F. 1994. Citrus variegated chlorosis: Axenic culture, pathogenicity, and serological relationships with other strains of Xylella fastidiosa. Phytopathology 84:591-597.

11. Hewitt, W. B. 1939. A transmissible disease of grapevine. (Abstr.) Phytopathology 29:10.

12. Hewitt, W. B., Frazier, N. W., and Houston, B. R. 1942. Transmission of Pierce's disease of grapevine with a leafhopper. (Abstr.) Phytopathology 32:8.

13. Hewitt, W. B. 1970. Pierce's disease of Vitis species. Pages 196-200 in: Virus Diseases of Small Fruits and Grapevines. N. W. Frazier, ed. University of California Press, Berkeley.
14. Hopkins, D. L. 1989. Xylella fastidiosa: Xylem-limited bacterial pathogens of plants. Annu. Rev. Phytopathol. 27:271-290.

15. Lopes, J. R. S. 2000. Transmission of Xylella fastidiosa in citrus and ecology of its transmission vectors. Intern. Soc. Citric. Congr. 2000:64.

16. Phillips, P. A. 1999. Vineyards, almond orchards threatened. Fruit Grow. 119:18F-18H.

17. Pooler, M. R., and Hartung, J. S. 1995. Genetic relationships among strains of Xylella fastidiosa from RAPD-PCR data. Curr. Microbiol. 31:134-137.

18. Pooler, M. R., and Hartung, J. S. 1995. Specific PCR detection and identification of $X y$ lella fastidiosa strains causing citrus variegated chlorosis. Curr. Microbiol. 31:377-381.

19. Pooler, M. R., Myung, S. R., Bentz, J., Sherald, J. and Hartung, J. S. 1997. Detection of Xylella fastidiosa in potential insect vectors by immunomagnetic separation and nested polymerase chain reaction. Lett. Appl. Microbiol. 25:123-126.

20. Purcell, A. H., and Finley, A. H. 1979. Evidence for noncirculative transmission of Pierce's disease bacterium by sharpshooter leafhoppers. Phytopathology 69:393-95.

21. Purcell, A. H., and Saunders, S. R. 1999. Glassy-winged sharpshooters expected to increase plant disease. Calif. Agric. 53(2):2627.

22. Purcell, A. H., Saunders, S. R., Hendson, M., Grebus, M. E., and Henry, M. J. 1999. Causal role of Xylella fastidiosa in oleander leaf scorch disease. Phytopathology 89:53-58.

23. Qin, X., Miranda, V. S., Machado, M. A., Lemos, E. G. M., and Hartung, J. S. 2001. An evaluation of genetic diversity of Xylella fastidiosa isolated from diseased citrus and coffee in Sao Paulo, Brazil. Phytopathology 91:599-605.

24. Raju, B. C., and Wells, J. M. 1986. Disease caused by fastidious xylem-limited bacteria and strategies for management. Plant. Dis. 70:182-186.

25. Roberto, S. R., Coutinho, A., Lima, J. E. O., Miranda, V. S., and Carlos, E. F. 1996. Transmissao de Xylella fastidiosa pleas cigarrinhas Dilobopterus costalimai, Acogonia terminalis e Oncometopia facialis (Hemiptera: Cicadellidae) em citros. Fitopatol. Bras. 21:517-518.

26. Rodriguez, C. M., Obando, J. J., Villalobos, W., Moreira, L., and Rivera, C. 2001. First report of Xylella fastidiosa infecting coffee in Costa Rica. Plant Dis. 85:1027.

27. Rossetti, V., Garnier, M., Bove, J. M., Beretta, M. J. G., Teixlira, A. R. R., Quaggio, J. A. and deNegri, J. D. 1990. Presence de bacteries dans le xyleme d'orangers atteints de chlorose variegee, unenovelle maladie des agrumes au Brasil. C. R. Acad. Sci. (Paris) 310:345-349.

28. Stoner, W. N., Stover, L. H., and Parris, G. K. 1951. Field and laboratory investigations indicate grape degeneration in Florida is due to Pierce's disease virus infection. Plant Dis. Rep. 35:341-344. 